\title{
VEZETÖI DILEMMÁK AZ ÉRTÉKESÍTÉSI UTAK ÁTALAKÍTÁSA SORÁN
}

Az értékesítési utak számának növekedése több iparágban elfogadott tény, s számos vállalat törekszik újabb értékesítési utak megnyitására. Az újabb utak eltérő piaclefedést biztosíthatnak, $s$ jellegük szerint akár tartósabb versenyelőnyt is biztosíthatnak a vállalat számára akár a kényelem, akár az imázs alapján. A magyar pénzügyi termékpiacon is jelentős elmozdulás történt újabb értékesítési utak megnyitása felé, ami különböző dilemmákat vet fel a vezetốk számára. A szerzók cikkükben két tényezốt emelnek ki: az on-line üzleti kapcsolat eltérố jellegét, valamint azt, hogy a vezetésnek - különösen az outsourcing esetében - mérlegelnie szükséges az esetleges etikai vagy akár jogi problémák megjelenését is.

Kulcsszavak: értékesítési csatornák, on-line értékesítés, pénzügyi termékek, biztosítási termékek

Egy termelő, szolgáltató vállalat számára gyakran nem lehetséges a végső́ árak befolyásolása, így mérsékelt befolyást képesek a kereslet alakulására gyakorolni. Számos iparágban a felhasználói, fogyasztói árak elszakadhatnak a termelói áraktól, gyakran alapvető́en befolyásolva a versenyt. A keresletet így a piacot befolyásoló közvetítő́k alakítják, hiszen gyakran ớk határozzák meg, hogy az egymással versenyzó termékek, márkák árai hogyan alakulnak egymáshoz viszonyítva.

Másképp alakul a helyzet akkor, ha a termelö- vagy szolgáltatóvállalat saját értékesítést (is) folytat, hiszen ekkorközvetlen hatással lehet a végső árakra. Egy több alkalommal elvégzett kutatás (Versenyben a világgal) tapasztalatai szerint a megkérdezett magyar vállalatok forgalmuk 40-50\%-át bonyolították le közvetlen formában; saját értékesítési irodán, saját ügynöki hálózaton és más közvetlen értékesítési formákon (direct mail, telemarketing, internet stb.) keresztül. Többségük azonban közvetítő́k segítségét vette igénybe.

Az értékesítési utak kialakításánál legalább két szempontot érdemes mérlegelni: a piaci lefedés képességét (el tudjuk-e érni a tervezett célcsoportot?) és a pénzügyi hatékonyságot (milyen költségek merülnek fel?). A hatásosság és hatékonyság egyensúlya változó lehet.

A magyar vállalatok viszonylag lassan indultak el a nem hagyományos értékesítési utak alkalmazása felé. Egy többször megismételt felmérés szerint a szokásos disztribúció jellemzó az értékesítésben (1. táblázat):
1. táblázat

Értékesítési utak megoszlása a magyar vállalatok körében

\begin{tabular}{|l|c|c|}
\hline \multicolumn{1}{|c|}{ Értékesitési ưt } & $\mathbf{1 9 9 6}$ & $\mathbf{2 0 0 4}$ \\
\hline Elektronikus kereskedelem & 0,1 & 0,8 \\
\hline Telemarketing & 0,1 & 0,7 \\
\hline Közvetlen postai út & 0,7 & 2,2 \\
\hline Saját ügynöki hálózat & 3 & 7 \\
\hline Közvetítõ kereskedó & 4 & 11 \\
\hline Kiskereskedelmi vállalat & 13 & 15 \\
\hline Nagykereskedelmi vállalat & 23 & 22 \\
\hline Saját üzleten keresztül & 49 & 45 \\
\hline Együtt & $\mathbf{1 0 0}$ & $\mathbf{1 0 0}$ \\
\hline
\end{tabular}

A viszonylagos stabilitás természetesen a teljes gazdaságra jellemző, fontos lehet tehát egy olyan iparág megismerése, ahol a változások gyorsabban és markánsabban jelennek meg. A nemzetközi piacokon a biztosítási ipar jelentôs változásokon ment keresztül, mint ezt Dumm és Hoyt (2003) bemutatta. A piaci telítődés és a termékek bonyolultságának változása a biztosítókat olcsóbb és hatékonyabb értékesítési utak keresésére buzdította. A hagyományos utak (iroda, saját ügynökhálózat) mellett megjelentek a viszonteladók (például bankok), s számos független ügynök és bróker, akik ma már az amerikai piaci tranzakciók zömét kezelik. 
Emellett megfigyelhető a termékek egy körének egyszerúsödése is, amely a fogyasztók növekvő internethasználatával párhuzamosan az online értékesítés irányába mozdította a piacot. Más kutatások ugyanis azt mutatták vö. van Birgelen, 2006), hogy a fogyasztók szívesen fogadják az on-line értékesítési megoldásokat, amennyiben azok az észlelt hatékonyságot növelik, míg a bonyolultabb termékek esetében elutasították azt.

Azt a kérdést, kívánja-e egy vállalat fogyasztóit újabb értékesítési utakra átvinni (migráltatni), számos szempont alapján lehet megítélni. Kumar (2005) szerint e szempontok a következók:

1. Mennyire vonzó az új értékesítési út a célcsoport számára? Sokszor ugyanis azt tapasztaljuk, hogy egy-egy új értékesítési lehetőség gyorsan felkeltheti a vevớk érdeklődését, gondoljunk például az intemetes vagy mobiltelefonos bankolásra.

2. Az új értékesítési út felé vándorolni kívánó csoport elég nagy-e ahhoz, hogy az értékesítési út múködtetése gazdaságos legyen? Természetesen az új utak kialakítása és menedzselése költségeinek az átlagos megtérülési idő́n belül célszerú visszatérülniük. Egy intemetes lehetőség megnyitása több tízmilliós befektetést és a mérettől függő múködtetési költséget feltételez. Végig kell gondolni tehát, milyen árakon értékesítjük az új lehetőséget, pl. havidíj stb. formájában.

3. Az új értékesítési úton mứködési előnyöket, vagy más pozicionálást kínálunk a vevóknek? Sok vevő azért választja az új értékesítési utat, mivel ez múködési elónyökkel jár számára, a fogyasztónak pl. nem kell a bankba mennie, hogy egy átutalást elintézzen, máskor pedig az image az, amelyik vonzó lehet számára. Ez mind a technológiai újításon alapuló értékesítésre, mind pedig a hagyományos, de a vevó számára új utakra (pl. kiemelt vevớstátus nyújtása) is érvényes lehet.

4. A költségek és az értéklánc szempontjából érdemes-e a vevớket az új értékesítési úton kiszolgálni? Az újabb értékesítési utak másfajta költségszerkezetúek lehetnek, mint a korábbiak. A telebanking esetében például számítani lehet arra, hogy a vevő́k a „szokásos” üzemidő́n kívül intézik ügyeiket, s ehhez erőforrásokat kell rendelni. Egy internetes vevơszolgálat esetében szintén hasonló a helyzet.

5. Képesek-e a versenytársak az új út megnyitására reagálni és milyen reakció várható?

A kezdeti versenyelöny könnyen csökkenhet, ha valamennyi versenytárs követi az első alkalmazót. Azt is mérlegelni szükséges, mennyire a kategóriát növeljük az új értékesítési út létrehozásával, s mennyire saját piaci részesedésünket.

6. Mennyire változtatja meg az új értékesítési út a jelenlegi utakat használó vevő́k preferenciáit? A korábban idézett tanulmány vö. van Birgelen, 2006) is jelzi, hogy a vevók preferenciái gyorsan változhatnak. Az egyszerúbb kiszolgálással például csökkenhet a vállalat által nyújtott szakértói tanácsadás értéke, azaz nem biztos, hogy egy egyszerúsítő, technológia alapú új értékesítési út bevezetése minden vállalat számára alkalmas lehet.

\section{Változó értékesítési utak a biztosítási piacon: esettanulmány}

\section{A biztosítási piac}

A lakossági biztosítási piac egyike a legdinamikusabban fejlődő piacoknak Magyarországon, hiszen az elmúlt években a növekedés rendre meghaladta a 20\%-os ütemet. Bár 2007. évi adatok még nem állnak rendelkezésünkre, 2006-ban a díjbevétel 830 milliárd forintnál magasabb volt, és 2007 III. negyedévében megközelítette a 700 milliárd forintot.

A számos biztosítási forma között dominál az életbiztosítási bevétel, amely az elmúlt években az összbevétel $\mathrm{kb}$. felét adta. A pénzügyi bevételek nagyszámú szerződéshez köthetốk, 2006-ban kb. hárommillió életbiztosítási szerződés volt érvényben. Látható tehát, hogy e szakma jelentős mértékben tömegesedett. (Az adatok a MABISZ 2007-es évkönyvéból származnak.)

Hasonlóan tömeges piacot testesít meg a kötelezó gépjármú-felelősségbiztosítási forma is, ahol 2006ban a szerződések száma megközelítette a négymilliót, nem kis mértékben annak köszönhetően, hogy a 2000es években jelentősen növekedett a gépjármúeladások száma, részben a finanszírozás könnyebbülése, részben pedig a vállalatok jelentốs marketingráfordításainak köszönhetően.

E tömeges piacok kiszolgálását egy összetett szervezetú iparág valósítja meg, amelyben - különösen az értékesítésben - egyre több szereplö jelenik meg. Mindenesetre érdemes megjegyezni, hogy a biztosítótársaságok és -egyesületek 26 ezer munkatársat foglalkoztattak, nagyrészüket azonban vállalkozóként (kb. 15 ezer föt). Az ágazat jelentősen növelte a termelékenységet, 1997-ben még 28 ezer fơvel ért el kb. 200 milliárdos díjbevételt, azaz a díjbevétel majdnem négyszeresére emelkedett. Legalább ennyire érdekes azonban az a tény, hogy a létszámcsökkenés alapvetően a fớallású munkatársak körében következett be, s a vállalkozóként foglalkoztatott munkatársak száma ez idő alatt majdnem kétszeresére nơtt. 


\section{A biztosítási verseny és szereplöi}

A biztosítások alapvetớen tudományos alapon nyugvó termékek, ahol az aktuáriusok feladata olyan díjszerkezet és befektetési politika kialakítása, amely ezen az erôsen szabályozott piacon lehetóvé teszi a megbízható és eredményes múködést. Természetesen a díjtételek nem függetlenek a versenytől sem, amely egyes termékkategóriákban igen éles lehet.

Amint a 2. táblázat alapján látható 1995 és 2006 között a piaci részesedés alapján változott a piacvezetố vállalatok sorrendje, valamint az iparágon belüli jövedelemeloszlás is.

2. tablazat

A vezetổ biztosítótársaságok piaci részesedése 1995-ben és 2006-ban, \%

\begin{tabular}{|l|c|c|}
\hline \multicolumn{1}{|c|}{ Biztosít6társaság } & $\begin{array}{c}\text { Piacrészesedés } \\
\mathbf{1 9 9 5}\end{array}$ & $\begin{array}{c}\text { Piacrészesedés } \\
\mathbf{2 0 0 6}\end{array}$ \\
\hline Hungária/Allianz & 34,7 & 21,0 \\
\hline ÁB-Aegon/Aegon & 23,9 & 9,1 \\
\hline Providencia/General & 11,6 & 14,9 \\
\hline N-N/ING & 11,4 & 14,0 \\
\hline Garancia/OTP Garancia & 4,6 & 9,7 \\
\hline
\end{tabular}

Forrás: MABISZ-évkönyvek

A 2007-es intézményi helyzet sok területen nehezen hasonlítható össze a kilencvenes évek közepén található állapotokkal. Egyrészt átalakultak a korábbi társaságok, a nemzetközi tulajdonosok részesedése megemelkedett, s olyan vállalatok kerültek előtérbe, amelyek késóbb indultak a magyar piacon, mint a korábbi duopolista piac két nagy szereplője, a Hungária (Allianz) és az Állami Biztosító (Aegon). Mint korábban említettük: az átalakulás jelentő́sen befolyásolta az üzleti modelleket. Csökkent a munkatársak száma, növekedett a termelékenység és átalakult az iparág technológiai szerkezete. A 2000-es évek elejére szinte valamennyi társaság jelentős számítástechnikai beruházást hajtott végre, lehetớvé téve a nagy adatbázisok összekapcsolását és az ügyviteli munka modernizálását, amihez a késóbbiekben az internet szerepének növekedése is hozzájárult.

Legalább ekkora változást hozott azonban az is, hogy a biztosítási piac liberalizálásával megjelentek a biztosításközvetítốk, az alkuszok. A biztosítási alkuszok tulajdonképpen független közvetítők, akik az ügyfél megbízásából szerzik be a biztosítást, ellentétben a biztosítók üzletkötớivel, akiket a biztosító azért fizet, hogy eladják termékeiket. Utóbbiakat gyakran nevezzük függó ügynöknek, míg az alkuszok függetlenek. Az alkuszok piacismeretükre támaszkodva kere- sik meg a legideálisabb ajánlatokat, figyelembe véve a vevớk igényeit, és - a fogyasztóvédelmi előírásoknak megfelelóen - legalább 3-4 biztosító ajánlatát mutatják be ügyfeleiknek.

A biztosításközvetítớk számát elég nehéz megbecsülni, az egyik nagy szervezet, a MABISZ tagjainak számát 12 ezer körülire becsülte 2006-ban, míg 2007-ben a Figyelốnet becslése szerint számuk 50 ezer körül mozgott. A biztosításközvetítők számára kötelezó a regisztráció, s a PSZÁF a - többszöri halasztás után - 2008-ban szakképesítés megkövetelését tervezi, ami az ügynökök számát várhatóan csökkenteni fogja. (2006-ban a közvetítők kb. 80\%-ának nem volt szakképesítése.)

\section{A biztosítási termékek}

A biztosítási termékek köre fokozatosan bövül, s a termékskálára az összetettség növekedése jellemzó. A lakossági piac elsó jelentős innovációját az ún. unitlinked, befektetéssel kombinált termékek bevezetése jelentette 1997-ben. Az elsó piacra lépó ING-t (akkor még N-N Biztosíto) hamarosan valamennyi biztosító követte. Becslések szerint a 2006-ban kötött életbiztosítások 37\%-a unit-linked biztosítás volt.

„A befektetési egységhez kötött (unit-linked) életbiztosítások a vegyes életbiztosítások által nyújtott szolgáltatásokat (kifizetés halálesetkor vagy tartam végén) ötvözik a befektetési alapok által kínált befektetési lehetôségekkel. A konstrukció lényege, hogy a szerzớdó által befizetett díjakat a biztosító által felkínált és a szerzớdó által kiválasztott befektetési alapokhoz hasonlító eszközalapokba fektetik, így a lejáratkori - vagy haláleseti - kifizetés mértékét elsősorban ezen alapok hozama határozza meg." (www.pszaf.hu)

A termék természetesen feltételezi, hogy a fogyasztó pontosan ismerje saját pénzügyi helyzetét, tisztában legyen a kockázati elemekkel is, amelyek a tradicionális életbiztosításoknál kevésbé jelennek meg.

A biztosítási termékek egy másik fejlődési lépcsőjét az ún. bankbiztosítás megjelenése jelentette. A bankbiztosítás komplex - és jogilag nehezen kezelhetơ - tevékenységeket fed le, amelyek alapvetően arra vonatkoznak, hogy a bankok biztosítási termékeket kezdenek értékesíteni. A megoldások az egyszerũ jutalékos értékesítéssel kezdódtek, amelynél fejlettebb megoldás, amikor a bank saját csoportjának biztosítási termékeit forgalmazza, míg végül az integrált termékfejlesztésben tetőzik. A bankbiztosítás „úttörője” Magyarországon az OTP Garancia Biztosító volt, amely korán hozzálátott a bankcsoport számára biztosítási termékek kifejlesztéséhez, amelyeket azok értékesítettek. Alapvetố biztosítási termékeket (élet, lakás, hitel- 
fedezeti, kártyához kötődő utazási biztosításokat) szinte minden bankfiókban vásárolhat a fogyasztó már a 2000-es évek elejétól.

$\mathrm{Az}$ utóbbi években azonban az irány megfordult, a biztosítási ügynökök (függó, független, alkusz stb.) is hozzáláttak banki termékek értékesítéséhez, s kínálnak különböző banki termékeket (alapvetően hiteleket) az ügyfél biztosítása mellé.

\section{Költségek és jutalékok}

A korábbiakban már említettük, hogy az üzletszerzés költségei dominálnak a biztosítók múködési költségei között. Az üzletszerzés költségeit elsődlegesen az ügynöki jutalékok határozzák meg. A jutalékok mértéke természetesen erósen változó, de pl. az életbiztosítási piacon a Figyelő úgy véli:

„Bár erról az ügyfelek ritkán értesülnek, egy hús-vér ügynök által személyesen eladott életbiztosítási szerződés jutaléka az éves biztosítási díj 40-150 százalékát is elérheti. (Egyébként ez az egyik oka annak, hogy ha egy életbiztosítási szerzódést idó elő́t felmondunk, akkor általában az első két éves díjat elbukjuk.) A súlyos jutalék magyarázatául a biztosítók a magas élőmunkaigénnyel érvelnek, mondván: egy kontraktust az ügynök általában két-három ,ülés' után tud csak tetó alá hozni, s személyesen, az ügyfél lakásán kell megjelennie, amit általában többszöri telefonos egyeztetés előz meg. A netes brókerek éppen ezt tudnák megspórolni, $s$ ha a kiemelkedóen magas ügynöki jutalék kikerülne a termék árából, elméletben még az ügyfél is jól járhatna: olcsóbban tudna biztosításhoz jutni." (Figyelö, 2007)

A jutalékokkal nem szokatlan a visszaélés sem, melynek egyik formája korábban az volt, hogy az ügynök összejátszott a vevővel, aki befizette az első negyedéves díjat, és utána felmondta a szerződést, az ügynök pedig zsebre tette a teljes jutalékot. Ennek kiküszöbölésére az egyes biztosítók eltérớ megoldásokat alkalmaztak:

„A jutalék alapja többnyire az éves díj, adott esetben a biztosítás futamideje, míg az egyedi típusú biztosításokra volumentől függóen magasabb jutalék járhat. Az Allianz és a K\&H a biztosítasi szerződésekre adott hónapban befolyt havi díjak alapján fizet jutalékot ügynökeinek. Az Aegon a három hónapnál korábbi belépók esetén ad a befolyt díj alapján szerzési jutalékot, de támogatja a kezdó üzletkötớk indulását is. A jutalék egészére azonban csak a 19. hónapban válnak teljesen jogosulttá. Fenntartási jutalékot 24 hónap múlva kapnak a befolyt díj alapján. Ugyanezt a módszert az Aegon csak a fél évnél rövidebb ideje neki dolgozó ügynökökkel szemben alkalmazza, a régi motorosok viszont már másfél év múltán is megkapják a kétéves díjfizetés után járó jutalékot. Emellett 1 százalék bonust kap az értékesítơ, ha ügyfeleinek legalább 86 százaléka rendben fizeti a biztosítási díjat, s további 1-1-et, ha ez az arány 90 százalék fölé emelkedik, illetve ha 96 százalékon is túlmegy".

(Biztosítási ügynökök: Helyszíni közvetítés, HVG, 2006. november 8.)

Mindezek mellett a személyes eladás jelentős költséget jelent a biztosítók számára, ezért több társaság is törekedett arra, hogy alacsonyabb költségư értékesítési utakat nyisson meg a fogyasztószerzés érdekében.

\section{Az értékesitési utak változása}

A hazai biztosítás „hőskorában” a biztosítási termékeket alapvetően a biztosítótársaságok irodai, vagy alkalmazotti státusban lévő kijáró ügynökei értékesítették. E területen az N-N biztosító agresszív, ügynökökre alapuló, kvázi MLM-rendszere hozta a legnagyobb változást, az életbiztosítási piacon az N-N rakétastartot vett, s személyre szabott tanácsadással, hólabdaszerú vevơi ajánlási rendszerével átalakította azt a képet, amit a magyar fogyasztók az életbiztosításról gondoltak. $\mathrm{Az}$ N-N (ma ING) fokozatosan átvette a vezetó szerepet az életbiztosítási piacon.

Mint korábban is láthattuk, a korai években a biztosítótársaságok alapvetóen saját, alkalmazott státusban lévő ügynökeikkel oldották meg a piac kiszolgálását, amelyet a fokozatos kiszervezések követtek. A kor hangulatát jól jellemzik a Figyeló 2001-ben megjelent cikkében írottak:

„Az ÁB-Aegonnál már 1996-1997-ben érezték, hogy kell valamit csinálni, mert a nyakukon van az N-N. A következó évben be is előzött a holland tulajdonú társaság" - emlékszik vissza Kovács Róbert vezérigazgató-helyettes. Először is arra az elhatározásra jutottak, hogy „le kell cserélni, akit le kell”. Szinte a teljes hálózati vezetới gárdában volt csere, $s$ az elmúlt négy-öt évben háromszor történt változás a felső vezetésben is. Az utóbbi azt eredményezte, hogy mára teljesen kicserélődött a gárda. Képzésre, oktatásra 2,53,0 milliárdot költöttek öt év alatt. A tréningek fontos részét képezte a felhatalmazó vezetés (empowerment) elterjesztése (Figyeló, 2001/19. szám). „Ez komoly szemléletváltozást hozott a cégnél. Ennek tudhatók be a sikereink: olyan vezetók kerültek a hálózat élére, akik képesek voltak másképpen gondolkodni" - állítja Kovács Róbert.

Az értékesítési hálózat egységeit 1997-1998 táján magánkézbe adták, ezek önálló vállalkozásként mứködnek. A régi rendszerben az ÁB-Aegon bérelte az irodákat, fizette a személyzetet, a telefonvonalat és egyebeket, most az ügynökségek vezetơivel kötnek 
vállalkozói szerzódést, s utóbbiak bérelnek irodát (ớk döntik el, hogy hol és mekkorát), ók fizetik a segítooket (annyit, amennyit jónak látnak), s úgy használják ki az informatika adta lehetôségeket, ahogyan tudják. Mindezért a biztosítótársaság jó teljesítményt vár el, s ezzel arányosan ad finanszírozást. A hálózati értékesítés élén negyven ember áll, ớk az úgynevezett franchise ügynökségek vezetôii - mint például Szakács Gábor -, hozzájuk kapcsolódnak a menedzserek, utóbbiakhoz pedig a 2,5-3 ezer üzletkötő, ő́k szintén vállalkozók. „Olyan struktúrát akartunk kialakítani, mint amilyen a fogyasztási cikkek piacán van. Az ott dolgozó cégek is elsősorban a kiváló termékek és szolgáltatások előállítására, valamint a marketingre koncentrálnak, az eladást pedig azokra bízzák, akik abban profik" - mondja Kovács Róbert, aki maga is az FMCG-szektorból érkezett." (Figyelö, 2001)

A kiszervezések mellett középpontba került az ügynöki munka technológiai fejlesztése is. Ez egy hoszszabb folyamat eredménye volt, hiszen a társaságoknak először át kell formálniuk teljes belsó informatikai rendszerüket ahhoz, hogy a képviselő́k hatékonyan legyenek képesek a vállalati rendszereket felhasználni, s nemsokára megjelentek a laptopos ügynökök, akik már képesek voltak az ügyfelek kérdésire azonnal szcenáriókkal válaszolni, a kiválasztott biztosítási konstrukció egyes paramétereit modellezni.

Az ügynöki értékesítés ugyanakkor nem képes a piacot teljes mértékben lefedni, s - mint ezt a késóbbiekben látni fogjuk - jelentôs költséget jelent a vállalatok számára. Nem meglepő tehát, hogy a biztosítótársaságok technológiaalapú megoldások után néztek.

„A hazai biztosítók közül három tekinthető nagyobb játékosnak az internetes/telefonos piacon. A legkomplexebb szolgáltatást az ÁB-Aegon, az Allianz Hungária és a Generali-Providencia nyújtja. Az ÁBAegonnál Vereczki András szolgáltatási igazgató elmondása szerint, a ,direkt' csatornák közül a telefonos call-center bizonyult elsődleges fontosságúnak, ezen évente egymillió megkeresést kapnak. Interneten évente alig néhány ezer szerződést értékesítenek. Kárbejelentésre, a kárrendezési folyamat elindítására ugyanakkor mindkét eszközt aktívan igénybe veszik a biztosítottak. Hasonló a helyzet az Allianz Hungáriánál is: az évi mintegy félmillió megkeresésból szintén 3-4 ezer üzletkötés születik, de lényegesen több üzlet elókészítése történik így. Tamás Gábor, a Direct Centrum vezetơje szerint az ügyfelek interaktivitása érzékelhetớen nớtt az utóbbi idóben: korábban csak tájékozódásra, információszerzésre használták az on-line eszközöket, ma már a komplexebb szolgáltatást és az erõsebb kontrollt is igénylik. A biztosítottak saját, tit- kos kódjukat használva ráláthatnak a biztosítónál kezelt adataikra, meggyớzódhetnek azok helyességéról, illetve változásáról. Ennek eredményeként az internet nemhogy gyengítené, hanem épp erősíti a biztosító és ügyfelei között nélkülözhetetlen bizalmi kapcsolatot véli Tamás.

A Generali-Providencia talán a legcsalódottabb a nagyok közül: esetükben mindössze ezer szerződés köttetik a direkt csatornákon évente. Fónai Imre marketingcsoport-vezetố szerint épp ezért nem az értékesítésre, hanem az aktív kommunikációra (kampányokra) és az ügyfélszolgálati funkciókra érdemes a hangsúlyt helyezni, igaz, épp ez a leginkább költségigényes terület." (Figyelö, 2004)

A direkt utak mind a telefonos, mind pedig az internetes értékesítést magukban foglalják, s az utóbbi idókben szerepük növekedett az egyes termékpiacokon.

\section{Egy közeli eset: A kötelezó gépjármú-felelốsség biztosítás piaca}

Legalább 2,5 millió egyéni ügyfél biztosítja gépjármúvét minden évben. E piaci terület azért is érdekes lehet számunkra, mivel a liberalizálás lehetớvé tette az egyes szolgáltatók között az árversenyt, s ezzel párhuzamosan segített a biztosítóváltás jogi és procedurális akadályainak lebontásában is.

Míg az első években szinte elhanyagolható volt a biztosítóváltások száma, 2007-ben kb. 700 ezren váltottak biztosítót a kötelezó piacon. A nagy nyertesek az on-line értékesító alkuszvállalatok voltak: a Netrisk, a biztositas.hu és a CLB. A becslések szerint a Netrisk a szolgáltatóváltók kb. 45\%-át szerezte meg, és sokat adott el a Generali Providencia által létrehozott Genertel termékeiból.

A kötelezó biztosítások piacán jelentős áresés volt megfigyelhetô, ami néhány esetben azonban a minőség romlásával is járt. 2006-ban a PSZÁF több biztosítóegyesületet eltiltott a kötelezó biztosítások értékesítésétól, mert az ügyfelek tájékoztatása elmaradt, a kárrendezés pedig akár fél évig is húzódhatott. Ennek ellenére 2008-ra az elörejelzés hasonló, sokan fognak váltani, föleg az on-line megoldást használva, $\mathrm{s}$ az online biztosításkötés erôsödik az életbiztosítások és lakásbiztosítások területén is.

Természetesen a párhuzamos értékesítési utak megnyitása felveti a kannibalizmus kérdését is, de pl. a Generali szakemberi optimisták e tekintetben:

„Érdekes kérdés az is, miként kezelik majd a cégek azt a helyzetet, hogy ugyanazon a piacon két-két társasággal lesznek jelen. ,Nálunk ez nem lesz probléma, mivel a két cég más-más ügyfélkörre fókuszál' mondta a Figyelő́nek Ilics László, a Genertel felügyeló 
bizottsági tagja. A direktbiztosító stratégiájának egy alapos piacfelméréssel ágyaztak meg, amiból az derült ki, hogy a fiatal és középkorú, felsớ- és középfokú végzettségư, nyitott, újdonságra fogékony, tehetôsebb és költségérzékeny réteg jó ügyfele lehet egy efféle vállalatnak." (Figyelő, 2007)

\section{A személyes értékesítés szerepe a változó piacon}

A fenti esetekból látható, hogy a piac változása során növekszik a termékismeret, s egyre több fogyasztó válik szakértővé. A szakértők számos tekintetben eltérnek az újonc fogyasztóktól, magatartásuk alapvető́n más.

$\mathrm{Az}$ is világos továbbá, hogy az eladási szervezetek nem változatlanok, azaz szerepük változásával struktúrájuk, méretük, költségvetésük is változhat. Zoltners és társai (2006) olyan modellt kínálnak, amelyben az üzleti életciklushoz (a termékéletgörbéhez hasonló, egy üzletre vonatkozó leírás) kötik az eladási szervezet legfontosabb paramétereit. Elképzelésük szerint a különbözó szakaszokban más és más feladat vár az eladószemélyzetre, és ehhez hasonlóan érdemes legfontosabb paramétereiket alakítani. A 3. táblázat ezt a felvetést mutatja be részletesebben.
A piacokhoz való alkalmazkodás során az eddigiekben csak a belsó megoldásokat elemeztük, $s$ nem merült fel a tevékenységkihelyezés kérdése. Ez a megoldás gyakran szokatlannak tứnhet, de látnunk kell, hogy a saját eladógárda általában a fix költségeket növeli, míg a harmadik fél által ellátott eladás elsődlegesen változó költséget jelent. Természetesen számos tényezốt kell mérlegelnünk ahhoz, hogy e kérdésre választ adhassunk. Felmerül az információellátás szerepe, a márka helyes pozicionálása és természetesen az irányíthatóság kérdése is. A kihelyezés növekvő szerepet tölt be az USAban, ahol az érvelés szerint a szakértő harmadik félnek alapvetően érdeke az eladás, s esetleg képes lehet arra, hogy olyan piacokon is megjelenjen több vállalat termékeivel, amelyre a saját vállalatnak esetleg nem érdemes külön eladógárdát kiépítenie, illetve fenntartania.

\section{A személyes értékesítés és az internet kölcsönös hatása}

A hibrid marketingrendszerek terjedését nagymértékben segíti az internet szerepének növekedése. Bár a tranzakciók és az üzletkötések esetében az internet aránya alacsony (illetve csak néhány termékkategória esetében magas), az eladási folyamat más szakaszaiban

\section{A sikeres eladási szervezet jellemzői}

\begin{tabular}{|l|c|c|c|c|}
\hline \multicolumn{1}{|c|}{ Szervezeti jellemzók } & Bevezetési szakasz & Növekedési szakasz & Érettségi szakasz & Hanyatlási szakasz \\
\hline Az eladószervezet szerepe & $\mathrm{xxxx}$ & $\mathrm{xx}$ & $\mathrm{x}$ & $\mathrm{xxx}$ \\
\hline A szervezet mérete & $\mathrm{xxx}$ & $\mathrm{xxxx}$ & $\mathrm{xx}$ & $\mathrm{xxxx}$ \\
\hline A szervezet specializáltsága & $\mathrm{x}$ & $\mathrm{xxxx}$ & $\mathrm{xxxx}$ \\
\hline Az erơforrás-szükséglet & $\mathrm{xx}$ & $\mathrm{x}$ & $\mathrm{x}$ \\
\hline A piaci feladat & $\begin{array}{l}\text { Az ismertség növelése } \\
\text { és az üzlet beindítása }\end{array}$ & $\begin{array}{l}\text { Penetráció és új szeg- } \\
\text { mentumok bevonása }\end{array}$ & $\begin{array}{l}\text { A meglévó vevók haté- } \\
\text { kony megtartása }\end{array}$ & $\begin{array}{l}\text { Hatékony megtartás, } \\
\text { illetve kilépés }\end{array}$ \\
\hline
\end{tabular}

A kezdeti szakaszban lényeges a gyors belépés a piacra, amely azonban általában még nem igényli az erós specializáltságot, éppen azért, mivel a piac még differenciálatlan. Az eladószervezet itt alapvető szerepet játszhat. A növekedés során már megjelenik a differenciálás, ezért növelni kell mind a szervezet méretét, mind pedig annak specializáltságát. A piacon egyre több új vevő́ jelenik meg ugyanis sajátos igényekkel. $\mathrm{Az}$ érett piacon már kevésbé várható a további differenciálás, de lényegessé válik a vevớk megtartása, olyan körülmények között, amikor a nyereségesség csökkenhet. Ha egy piac jól reagál az eladószervezet erőfeszítéseire, célszerú lehet invesztálni. A hanyatlás szakaszában minden nap számíthat, így érdemes a szervezet méretének esetleges gyors csökkentése. szerepe igen jelentốs. A személyes eladásra gyakorolt hatást elemezve célszerúbb egy tágabb megközelítést bemutatnunk, amely fogyasztói oldalról elemzi az internet lehetséges fogyasztói elónyeit. Keeney (1999) cikkében az internetes kereskedelem céljait a 4. táblázat szerint vázolta fel.

A klasszifikáció széleskörúen veszi számba azokat a potenciális tényezóket, melyek értéket alkothatnak az internetes kereskedelmet használó fogyasztók számára. Ily módon jóval szélesebb értelmezéshez juthatunk, mintha csak a klasszikus közgazdasági paramétereket, az árat és a keresési költségeket vennénk figyelembe. Elemzésünkben először mégis e tényezók hatását vizsgáljuk, majd kitérünk azon változókra is, amelyek a klasszikus közgazdasági elemzés határán kívül esnek. 
Az internetes kereskedelem lehetséges céljai

\begin{tabular}{|c|c|}
\hline Általános cél & A vásárlás idejének csökkentése \\
\hline $\begin{array}{l}\text { A fogyasztói elégedettség maximalizálása } \\
\text { A feldolgozási idô maximalizálása } \\
\text { A termékminóség maximalizálása } \\
\text { A ternnékérték maximalizálása } \\
\text { Minôség egyenletessége } \\
\text { A legjobb ár/érték arány } \\
\text { A funkcionalitás maximalizálása } \\
\text { Költségcsökkentés } \\
\text { A termékköltség csökkentése } \\
\text { A szállítási költség minimalizálása } \\
\text { Az internetköltség minimalizálása } \\
\text { Az utazási költség minimalizálása } \\
\text { A termék kézhezvételének gyorsítása } \\
\text { A szállítási idó minimalizálása } \\
\text { A logisztika idejének csökkentése } \\
\text { A kényelem maximalizálása } \\
\text { A vásárlási kényelem növelése } \\
\text { A rugalmasság növelése } \\
\text { A vevớszolgálat javítása } \\
\text { A visszaküldés javítása } \\
\text { A vásárlási erôfeszítés csökkentése } \\
\text { A ternnék megtalálásának javítása } \\
\text { A káros kömyezeti hatások minimalizálása }\end{array}$ & $\begin{array}{l}\text { A vásárlási idố minimalizálása } \\
\text { A fizetési idô minimalizálása } \\
\text { A várakozás minimalizálása } \\
\text { A termékkeresési idó minimalizálása } \\
\text { A kommunikáció idejének minimalizálása } \\
\text { A keresési idó minimalizálása } \\
\text { A rendelési idô minimalizálása } \\
\text { Az információgyưjtés idejének minimalizálása } \\
\text { A választás idejének minimalizálása } \\
\text { A magánszféra védelme } \\
\text { A spam-ok elkerülése } \\
\text { A vásárlási élvezet maximalizálása } \\
\text { A vásárlás társadalmi eseménnyé tétele } \\
\text { Az aggódás minimalizálása } \\
\text { A fogyasztók lelkesítése } \\
\text { A felhasználás hatékonyságának növelése } \\
\text { A csalódás minimalizálása } \\
\text { A fogyasztói bizalom növelése }\end{array}$ \\
\hline
\end{tabular}

Forrás: Keeney (1999)

Az internet egyik legfontosabb üzleti elónye a vevőkiszolgálás automatizálása, a vevő bevonása az eladási folyamatba. A hozzáférhetôség megteremtése révén jelentősen csökkenthető a vevớkiszolgálásra fordított költség, sok folyamat automatizálható, illetve a vevók bevonhatók az eladási folyamatba. Közgazdasági szempontbol a keresési költségek fogalmával kezelhetjük e kérdést: milyen mértékú keresési költséget hajlandók a vásárlók elviselni, illetve ą eladónak vagy a vevớnek kell-e a keresés költségeit fedezni.

A keresési költségek jelentős szerepet játszanak a közgazdaságtanban és a fogyasztói választások elméletében. Eszerint, a fogyasztók addig keresnek, amíg a keresésből származó határhasznosság megegyezik a keresés határköltségével. A keresési költségek öszszefüggnek az értékesítési rendszer makroszintú hatékonyságával. Mint Bucklin (1967) ezt elemezte, makroszinten találhat 6 egy olyan optimum, ahol a fogyasztók keresési költsége megegyezik az értékesí- tés egységköltségével és a rendszer szintû összköltség minimális. Bucklin példaként egy adott termék értékesítési hálózatának súrưségét hozta fel. $\mathrm{Ha}$ az értékesítési helyek száma alacsony (a marketingirodalomban gyakran exkluzív értékesítésként említve), az eladó költsége minimális, míg a vevőké igen magas. Ellenkező esetben, amikor az értékesítési helyek száma igen magas, a helyzet pont fordított. E gondolathoz több megjegyzést is kell füznünk. Egyrészt, az adott felállás jelentősen függ a termékek jellegétől. Az egyedi termékek esetében a vevớk magasabb keresést hajlandóak magukra vállalni, míg a tömegtermékek esetében nyilvánvalóan nem. A másik megjegyzés intézményi, a hiánygazdaságban a kereskedelmi beruházásokat mesterségesen fékezték és visszaszorították, és a tömegtermékek is kevés értékesítési ponton voltak hozzáférhetők. E jelenség, valamint a gyakori áruhiányok jelentôsen megemelték a fogyasztók keresési költségeit. 
Wernerfelt (1994) Bucklin gondolatára építve kísérli meg az általa bevezetett hatékonysági kritériumot (effeciency criterion) a marketing bizonyos kérdéseiben alkalmazni. A hatékonysági kritérium az értékesítési rendszer részének tekinti a fogyasztót és Paretooptimum elérésére, esetleg az eredmények összegének maximalizálására törekszik (maximization of joint payoff). Bármely marketingmegoldás, amely nem az összeredmények maximalizálására törekszik, nem hatékony azzal a megoldással szemben, amelyekben a játékosok megegyeznek a közös eredmények maximalizálásában, a nyereségek megosztásában. Wernerfelt azt állítja, hogy a vállalatok a hatékonyság kritériumát használják akkor, ha termékdesignnal vagy a gyártói funkciókkal kapcsolatos döntéseket hoznak, és eröfeszítéseket tesznek az információcsere érdekében. A szerzó elméletét az alábbi példákkal támasztja alá:

- az alacsony példányszámú termékeket nagyobb valószínúséggel árulják postai úton (internetes gyógyszer-kereskedelem valós fenyegetése),

- a jobban informált vásárlók nagyobb valószínúséggel veszik igénybe a csomagküldést,

- a reklámozásra leggyakrabban a piac legkoncentráltabb oldalain kerül sor,

- a nagyobb keresési költségú termékeknek nagyobb a kiskereskedelmi támogatottságuk,

- ha a vásárló ideje drága, az eladónak nagyobb az információnyújtási költsége,

- a jobb minőség erốteljesebb reklámozást igényel,

- csomagküldő szolgálatok esetén a teljes körú garancia fontos a siker eléréséhez.

Wernerfelt szerint elméletileg elérhető egy olyan megoldás, amelyben az egyik szerepló (például a termeló) lemond profitjának egy bizonyos részéról, költséget vállal magára a vevó informálása érdekében és evvel azt (lyvan döntéshez segíti, amellyel az összes nyereség mindkettejük számára magasabb (a jobban informált fogyasztó segíti pl. a kapacitáskihasználást a termelő, illetve kereskedő esetében). Közismert példa a marketingben az IKEA esete, amely rábírta vevớit, hogy vállaljanak nagyobb részt az értékalkotásban, s vegyenek át feladatokat a vállalattól. Az IKEA vevơi részt vállalnak a termelésben (összeszerelik a bútort), a szállításban, és felkészülten érkeznek a boltokba, ezáltal módosítva az eladók feladatait, akik jól felkészült vevớkkel állnak szemben, és így az információnyújtás mellett több idejük marad az aktív eladásra.

$\mathrm{Az}$ internetes megoldásokkal tehát az eladási folyamat egyes részeit átadhatjuk a vevőknek, természetesen annak megfontolása után, vajon érdekünk-e ez. Ha ugyanis a vevớk jobb informáltságukat az árak csökkentésére használják fel, akkor mérlegelendó, nem érdemes-e az informácio-hozzáférést korlátozni.

A korai internetes üzleti modellekról azt hitték, hogy a dezintermediáció (közvetítók megszúnése) széles körú elterjedéséhez vezetnek (1. ábra). Ekkor olyan állításokkal találkozhattunk, hogy az amazon.com a végét jelenti a könyvesboltoknak, az on-line banking a tradicionális bankfí́kok bezárásához vezet stb. Ténylegesen azonban reintermediációt (a közvetítók újra megjelenése) figyelhetünk meg:

1. Az internetes üzleti modellek nagy része gyorsan más üzleti típusba alakult át - pl. az amazon.com is sokkal több, mint egyszert könyvelad6.

2. A tradicionális közvetítớk válaszul változtattak korábbi elképzeléseiken és elkezdtek másfajta hozzáadott értéket adni a fogyasztók számára pl. a Waterstone és Borders fokozott és különleges könyvvásárlási élményt ajánl, míg a bankok az on-line szolgáltatásaikat a tradicionális mưveleteikbe integrálták.

1. abra

Az internet hatása az értékesítésre

\begin{tabular}{|c|c|c|c|}
\hline \multirow{2}{*}{\multicolumn{2}{|c|}{ A hatás típusa }} & \multicolumn{2}{|c|}{ A hatás helye } \\
\hline & & Belsó & Külsó \\
\hline \multirow{2}{*}{$\begin{array}{l}\text { A hatás } \\
\text { típusa }\end{array}$} & $\begin{array}{l}\text { Dezinter- } \\
\text { mediáció }\end{array}$ & $\begin{array}{l}\text { Tradicionális } \\
\text { szervezeti } \\
\text { funkciokrol valo } \\
\text { lemondás }\end{array}$ & $\begin{array}{l}\text { Tradicionális } \\
\text { közvetítőkrơl való } \\
\text { lemondás }\end{array}$ \\
\hline & $\begin{array}{l}\text { Reinter- } \\
\text { mediácio }\end{array}$ & $\begin{array}{l}\text { Új típusú } \\
\text { szervezeti } \\
\text { funkciok } \\
\text { kialakulasa }\end{array}$ & $\begin{array}{l}\text { Ưj típusú } \\
\text { közvetítők } \\
\text { kialakulása }\end{array}$ \\
\hline
\end{tabular}

Forrás: Piercy és Lane (2003)

Érdekes párhuzam, hogy a dezintermediáció és a reintermediáció hasonló módon mehet végbe a szervezeten belül, az eredmények azonban mindkét esetben meglepóek lehetnek. Az internetes kezdeményezések közvetlenül vagy közvetetten az eladószervezet leépítéséhez vezetnek (dezintermediácio). Ugyanakkor az is megfigyelhetô, hogy a tradicionális eladási tevékenységek valami mássá alakulnak (reintermediáció). Ebben az értelemben a sales menedzserek számára a kihívást az jelenti, hogy azonosítani tudják a szerkezeti változások ezen folyamatait, és hogy meg tudják tervezni a jövő eladószervezetét, mint egy új típusú szervezeti közvetítớt. A kihívás az, miként lehet az eladószemélyzetet egy versenyképes stratégiához hozzáilleszteni (Olson et al., 2001). 
Az interneten keresztül történő üzletkötés gyakran azonos idóben, de személytelenül történik, amely speciális helyzeteket hozhat létre az eladási folyamatban, az eladási tárgyalás során.

A tárgyalás interperszonális döntéshozási folyamat, ahol két vagy több ember kölcsönösen dönt a szúk erőforrások elosztásáról. A tárgyalás egymással ellentétes törekvéseket foglal magába, hiszen a tárgyalók egyrészt motiváltak abban, hogy együttmúködjenek az egyezmény megkötése érdekében, másrészt pedig versengenek egymással az erőforrásokért A tárgyalás során tehát a kulcsfeladatok: növelni az eróforrások tortáját (kooperatív aspektus) és igényt tartani az eróforrásokra (kompetitív aspektus). Az integratív tárgyalás az a folyamat, amikor a felek kölcsönös elónyt jelentó egyezségre jutnak. Vagyis ha a feleknek különbözó preferenciái, hiedelmei és érdekei vannak, akkor lehetséges olyan eredmények kiokoskodása, amelyek mindkét oldal számára kedvezóbbek, mint az egyszerú ,félbevágjuk” technika. Sajnos azonban a legtöbb ember csak fix tortát észlel, azaz úgy gondolja, hogy a másik fél érdekei teljesen ellentétesek az övével, ezért elmulasztják a kölcsönös előnyhöz jutás lehetôségét. Ez különösen azért ironikus, mert a legtöbb tárgyalási szituációban megvan ennek feltétele, ugyanakkor a fix torta feltételezése meglehetősen nagyhatású és meggyőzó̋ heurisztikának bizonyul. Thompson és Hrebec (1996) metaanalízise feltárta, hogy az emberek az esetek kb. 50\%-ában nem ismerik fel a másik fél érdekeit. Amikor arról üzletelnek, hogy ki, milyen mértékben tarthat igényt az erőforrásokra, az a disztributív tárgyalás. Ilyenkor a megegyezéshez mindenképpen szükség van egy pozitív megegyezési zónára, ahol a két fél elképzeléseinek van közös metszete.

Az információs technológián keresztül történó tárgyalás során mérlegelnünk szükséges az alábbi szempontokat:

\section{Interperszonális összhang}

Az összhang annak érzete, hogy az egyén szinkronban van a másik féllel a tárgyalás során. Tickle-Degnen és Rosenthal (1990) az összhang három összetevójét írták le: 1. kölcsönös figyelmesség (az én figyelmem rád, a te figyelmed rám irányul), 2. megbízhatóság (barátságosak vagyunk egymással szemben), és 3. koordináció (összhangban vagyunk, ezért spontán módon reagálhatunk egymásnak). Az empirikus vizsgálatok szerint az összhang javítja a társadalmi interakció minóségét. Több szemtól szembeni találkozás nagyobb összhangot eredményez, s kedvezóbb eredményeket jelent mindkét fél számára. Drolet és Morris (1995) vizsgálata szerint az összhang kialakulása meghatáro- zó volt abból a szempontból, hogy létrejött-e a megfeleló bizalom az integratív egyezség megkötéséhez. A nonverbális jelek az összhang eléréséhez kulcsfontosságúak.

\section{Koordináció}

A koordináció a tárgyalók megegyezésre való képességét jelenti. Bizonyos helyzetekben például nincs az ajánlatoknak közös metszete (az eladó nem akar alább menni az árban, a vevő pedig nem akar többet adni érti), s ilyenkor nem alakul ki pozitív megegyezési zóna.

\section{Információ}

A fizikai közelség bizonyos elő́nyöket jelent az információcsere szempontjából. Azoknak az embereknek, akik fizikailag közel vannak egymáshoz, lehetőségük van a többszöri találkozásra. Az alkalmi beszélgetések, amelyekre az egyének a pihenőszobában a kávéfözó mellett vagy útban az ebédló felé kerítenek sort, számos bonyolult tárgyalási probléma megoldására szolgálnak. A konfliktusok megnyilvánulnak, felismerik és sokkal gyorsabban kezelik óket, ha az egyének fizikailag közel vannak egymáshoz. Több információt is cserélnek ilyenkor egymással. Az emberek ugyanakkor gyorsabban beszélnek, mint írnak vagy gépelnek, ezért ugyanannyi információ kicserélése e-mailen keresztül sokkal lassabban történik. A szemtől szembeni kommunikáció egyik potenciális hibája azonban, hogy a felek hajlamosak teljesen lényegtelen, nem igazán feladatspecifikus irányba is elmenni.

\section{Társadalmi utánzás}

A társadalmi utánzás hatás, attitüd vagy viselkedés terjedése A személytől (küldő) B személyig (fogadó), ahol a fogadó nem észleli a küldó befolyásolási szándékát (Levy - Nail, 1993). A visszhang azt jelenti, hogy az egyén automatikusan utánozza a másikat, például köhögnek, tüsszentenek vagy ásítanak, amikor partnerük, hozzáigazítják aktivitásukat a másik aktivációs szintjéhez vagy szabályozzák nézésüket.

Az emocionális fertózés során az egyének utánozzák a másik arckifejezését és viselkedését, hogy ugyanazokat az érzelmeket éljék át, amelyeket partnerük érez. A kaméleon effektus során az egyén tudattalanul utánozza a másik arckifejezését, modorát, testtartását és viselkedését. Thompson és Nadler (2002) szerint az elektronikus kommunikációban részt vevő́k is tudattalanul utánozzák egymást, s nem csupán a nyelvi szerkezetekben (pl. üzenet hosszúsága, információs tartalma, nyelvtana), hanem társadalmi-érzelmi vonatkozásban is (pl. hangvétel, közvetlenség), ső́t még abban is, hogy az üzenetnek mekkora figyelmet tulajdonítanak 
(pl. válaszolás időtartama). A kapcsolat minớségét például jelentốsen befolyásolja, hogy kritikus idôszakban mekkora az e-mailre adott válasz késése.

$\mathrm{Az}$ elektronikus módon kommunikálók könnyen kifejthetnek normaszegớ magatartást, hiszen nem kell társadalmilag elvárt módon maszkírozni magukat.

Másrészrôl a komputeren keresztül történố kommunikáció pozitív viselkedést is kiválthat a csoport tagjaiból. Erốs csoportnormák alakulhatnak ki például, mivel a csoportkép nem fertốzôdik a személyes jelenléttel, ugyanakkor jobban is azonosulnak a csoporttal, és sokkal kedvezóbb benyomásuk alakul ki a másikról, mint szemtốl szembeni kommunikáció esetén.

Thompson és Nadler megállapításait az 5. táblázatban foglaljuk össze. sik hitelintézet kedvezôbb kondíciójú szerződésének keretében folytathassák tartozásuk törlesztését. A jelenség hátterében legalább három tényezốt fedezhetünk fel (lásd külön), de a legvalószínứbb ok mégis az, hogy az ügyfelet rábeszélték a váltásra. A korábban inkább csak a biztosítási piacon nyüzsgó ügynökök nagyjából két-három éve kezdték elárasztani a lakossági hitelpiacot is, $s$ ténykedésük napjainkra már-már kritikus méreteket öltött. Az MNB Klub legutóbbi rendezvényén az egyik jegybanki szakértő arról beszélt, hogy több banknál már az új hitelkihelyezések 60 százalékát is eléri a független közvetítoók közrem ḱködésével megkötötı szerzódéses állomány aránya. Sớt, a saját értékesítési hálózattal nem rendelkezó, tehát e tekintetben speciális finanszírozó vállal-

5. táblázat

Tárgyalás interneten keresztül

\begin{tabular}{|c|c|c|}
\hline & Társadalmi eredmények & Gazdasaggi eredmények \\
\hline $\begin{array}{l}\text { Interperszonális } \\
\text { tényezók }\end{array}$ & $\begin{array}{l}\text { A szemtôl szembeni kommunikációval } \\
\text { összehasonlítva az e-mail csökkenti az összhang } \\
\text { kialakulását. } \\
\text { A rövid telefonhívások a kooperáció magasabb } \\
\text { fokát és jobb munkakapcsolatot tesznek lehetóvé, } \\
\text { mint az e-mail. } \\
\text { Azok a tárgyalók, akik összhang elérésére } \\
\text { törekszenek, sokkal pozitívabb érzelmeket és } \\
\text { nagyobb bizalmat képesek kiváltani, mint akik } \\
\text { dominanciára tömek. }\end{array}$ & $\begin{array}{l}\text { A szemtól szembeni kommunikációval } \\
\text { összehasonlítva az e-mail növeli a több kimenetela } \\
\text { ajánlatokat. } \\
\text { A rövid telefonhívások jobb eredményeket émek el, } \\
\text { mint az e-mail. } \\
\text { A rövid személyes feltárulkozás csökkenti a } \\
\text { holtpontra jutás valószínưségét. }\end{array}$ \\
\hline $\begin{array}{l}\text { Csoport- és szociális } \\
\text { identitás tényezók }\end{array}$ & $\begin{array}{l}\text { A csoporton kívüli elektronikus tárgyalók sokkal } \\
\text { negatívabb hatást fejtenek ki és alacsonyabb } \\
\text { összhangot tudnak elérni, mint a csoporton } \\
\text { belüliek. } \\
\text { A férfi elektronikus tárgyalók a férfiakkal kevés.bé } \\
\text { együttmứködó munkakapcsolat elérésére képesek, } \\
\text { mint a férfiak a nôkkel. }\end{array}$ & $\begin{array}{l}\text { Azok a tárgyalók, akik a csoport hímevért } \\
\text { aggódnak, sokkal agresszívebb stratégiát használnak, } \\
\text { s ezért gyengébb eredményeket is érnek el, mint } \\
\text { azok, akiknek személyes hímevük a fontos. } \\
\text { A csoporton kívüli tárgyalók gyakrabban jutnak } \\
\text { holtpontra, mint a csoporton belüliek. }\end{array}$ \\
\hline
\end{tabular}

Forrás: Thompson és Nadler (2002)

\section{Az új értékesítési utak bevezetésének további szempontja: az etikus magatartás}

A biztosítási piachoz hasonlóan a lakossági hitelpiacon is jelentớs a változás, a pénzügyi szolgáltatók újabb és újabb termékeket vezetnek be. A fogyasztói reakciók vegyesek, de sokan hajlandóak egy-egy újabb konstrukciót választani. Hogy mennyire megalapozott választásuk, ezt a kérdést sokan vitatják. Az alábbi példa is erre utal:

„Trendivé vált a hitelkiváltás az idei tavaszon: adósok tömegei cserélik le bankjukat, hogy egy má- kozásoknál, mint például a BG Hitel és Lízingnél ez az arány a 70 százalékot is eléri, de a fiókokkal jól ellátott nagybankoknál is visszaszorul a klasszikus értékesítési csatorna szerepe." (Ügynökbuli, Figyelö, 2008. május 15.)

A cégen belüli üzletkötớk és közvetítôk közötti intenzívebb verseny megnöveli annak valószínüségét, hogy az eladószemélyzet etikátlan akciókat kezdeményez (Belizzi, 1995). A menedzserek a motivációs, javadalmazási és jutalmazási struktúra megfelelő kialakításával tudják a problémát kezelni.

Ugyanakkor felmerült annak a kérdése is, mennyire a vevő, és mennyire az ügynök érdeke az új konstrukciók választása: 
„Kérdésünkre több banki szakember is problémaként említette, hogy a közvetítók tájékozottsága nem megfelelő, az ügyfelek nem jutnak tőlük kellő információhoz, így gyakran a szerződéskötéskor nincsenek tisztában azzal, hogy mit is vállaltak valojában. Az ügynökökön keresztül létrejött hitelportfólió minősége - bár statisztikák nincsenek erról - a tapasztalatok szerint rosszabb a fiókban szerződó ügyfelekénél. Nem véletlen, hogy néhány banknál a közvetítók tevékenységét az adósok és a hitelezók szempontjából is igen károsnak tartják - van, aki egyenesen ügyfélrablásnak minősíti -, és nem csak azért panaszkodnak, mert elveszítik a szerződốk és a profit egy részét, de azért is, mert a hektikusan változó állomány megnehezíti a források tervezését és a portfólió kezelését." (Ügynökbuli, Figyeló, 2008. május 15.)

Ebben az esetben egyértelmúen sérül a fogyasztók szuverenitása. A kereskedelmi gyakorlat etikája a fogyasztói szuverenitás három kritériumára kell, hogy épüljön: a fogyasztók képességei, a fogyasztók információval való ellátottsága (informáltság), valamint a fogyasztó választása (6. táblázat). A fogyasztó szuverenitásának biztosítása azt a fajta szemléletet kívánja meg a vállalattól, amely a marketing lényege, vagyis a vevőorientációt, a fogyasztó érdekeinek prioritásként való kezelését. Ezen nézet szerint szükségszerú a vevő szuverenitásának biztosítása még akkor is, ha azt a piaci feltételek nem is kényszerítik ki (6. táblázat).

\section{A fogyasztó szuverinitásának dimenziói}

\section{6. táblazat}

\begin{tabular}{|l|l|}
\hline \multicolumn{1}{|c|}{ Dimenzió } & \multicolumn{1}{c|}{ Megfeleltetés } \\
\hline A fogyasztó képességei & $\begin{array}{l}\text { Sebezhetơségi faktorok: } \\
\text { életkor, képzettség, jövedelem } \\
\text { stb. }\end{array}$ \\
\hline $\begin{array}{l}\text { Információ (hozzáférhetơség } \\
\text { és minớség) }\end{array}$ & $\begin{array}{l}\text { Elegendó információ áll-e } \\
\text { rendelkezésre }\end{array}$ \\
\hline $\begin{array}{l}\text { Választás (lehetơség az } \\
\text { átváltásra) }\end{array}$ & $\begin{array}{l}\text { A verseny szintjeÁtváltási } \\
\text { költségek }\end{array}$ \\
\hline
\end{tabular}

Forrás: Smith es Quelch (1993)

Etikai problémák akkor merülnek fel, amikor a fogyasztók szabad akaratát szüntetik meg különféle pszichológiai trükkökkel. Az értékesítő́k alkalmazhatnak különféle módszereket, hogy legyőzzék a vevő természetes észlelési védőkorlátait. Számos technika tulajdonképpen pszichológia csapdát állít fel a vevő számára.

A fogyasztói szuverenitás sérülése azonban természetesen nem kizárólag az üzletkötőkre vezethető vissza. A vevő́k, ha nem kellő́en körültekintőek, maguk is tehetnek róla, ha elő́nytelen szituációba kerülnek. Ráadásul a többfordulós játszmák esetén az értékesítơnek játékelméleti szempontból sem éri meg tisztességtelennek lennie, hiszen a magatartása retorziót vonhat maga után.

A kérdés természetesen vezetôi figyelmet is igényel, hiszen az esetleges vevơi elégedetlenség a vállalatra lehet negatív hatással. Felvetódik tehát, milyen megoldást válasszon a vállalat, ha közvetítő́ket használ termékei eladásához. A közgazdasági elmélet általában a megbízo-ügynök dilemmára vezeti vissza e kérdést, amikor az ellenőrzés mértékét optimalizálással dönthetjük el. A tranzakciós költségek elmélete pedig valószínúleg a vállalat-ügynök közötti bizalom növelését is figyelembe venné. Ennél azonban radikálisabb megoldások is lehetségesek, a magyar piac egyik vezetó biztosítoja nem vesz igénybe harmadik felet az értékesítésre, $s$ nem tervezi az on-line út megnyitását sem.

\section{Összefoglalás}

Az értékesítési utak számának növekedése több iparágban elfogadott tény, s számos vállalat törekszik újabb értékesítési utak megnyitására. A szokásos közgazdasági nézópont - kannibalizációs veszteségek - mellett lényeges, hogy megértsük, az újabb utak eltéró piaclefedést biztosíthatnak, s jellegük szerint akár tartósabb versenyelőnyt is biztosíthatnak a vállalat számára, akár a kényelem, akár az imázs alapján.

Mint a rövid esettanulmány is mutatta, a magyar pénzügyi termékpiacon is jelentôs elmozdulás történt újabb értékesítési utak megnyitása felé, ami különbözó dilemmákat vet fel a vezetốk számára. Cikkünkben két tényező́t emeltünk ki: az on-line üzleti kapcsolat eltérő jellegét, valamint azt, hogy a vezetésnek - különösen az outsourcing esetében - mérlegelnie szükséges az esetleges etikai, vagy akár jogi problémák megjelenését is.

\section{Felhasznált irodalom}

Belizzi, J. A. (1995): Committing and Supervising Unethical Sales Force Behavior: The Effects of Victim Gender, Victim Status, and Sales Force Motivational Techniques. Journal of Personal Selling \& Sales Management, 15, Spring, $1-15$.

Chandy, R. K. - Tellis, G. J. - Macinnis, D. J. (2001): What to Say When: Advertising Appeals in Evolving Markets. Journal of Marketing Research, Vol. XXXVIII (November), 399- 414.

Csanyi S. (2007): A verseny és transzparencia kérdései a bankszektorban, elôadás, II. Bankkonferencia, 2007. november 6-7., Visegrád

Dumm, R. E. - Hoyt, R. E. (2003): Insurance Distribution Channels: Market in Transition. Journal of Insurance Regulation, 22, 1, 22-43. o. 
Holak, S. L. - Tang, Y. E. (1990): Advertising's Effect on the Product Evolutionary Cycle. Journal of Marketing, Vol. 54 (July 1990), 16-29.

Kehrer, K. - Keffer, W. (2003): Delivery channels for bank insurance, ABA Banking Journal, October, 95, 10-12.

Smith, C. N. - Quelch, J. A. (1993): Ethics in Marketing. Irwin, Homewood

Thompson, L. - Nadler; J. (2002): Negotiating via Information Technology: Theory and Application. Journal of Social Issues, Vol. 58, No. 1, 109-124.

Van Birgelen, M. - De Jong, A. - De Ruyter; K. (2006):
Multi-channel service retailing: The effects of channel performance satisfaction on behavioral intentions. Journal of Retailing, Vol. 82, 4, 367.

Zettelmeyer, F. (2000): Expanding to the Internet: Pricing and Communication Strategies When Firms Compete on Multiple Channels. Journal of Marketing Research, Vol. XXXVII August, 292-308.

Zoltners, A. A.- Sinha, P. - Lorimer, S. E. (2006): Match your sales force structure to your business cycle. Harvard Business Review, July-August

\section{Hibaigazítás}

Tisztelt Olvasók!

A Vezetéstudomány 2008. július-augusztusi számában Szabó Katalin (szerk.): Összehasonlító gazdaságtan címư könyvének ismertetésekor a tankönyv szerzóit tévesen ismertettük. Az ismertetó javítása folyamatban van, azt októberi számunkban közöljük.

$\mathrm{Az}$ érintettektől elnézésüket kérjük.

A szerkesztőség
Dear Readers!

In our latest issue (Vezetéstudomány, 2008.7.-8. szám) on the 29. and the 44. pages reference to the organiser of the konference wasn't correct. The correct sentece:

The study was presented at a conference organised by Corvinus University of $\mathrm{Bu}$ dapest and supported by the International Visegrad Fund and the Regional Studies Association.

Sorry for the mistake! 